„Bohemistyka” 2021, nr 1, ISSN 1642-9893

Mieczysław BALOWSKI

DOI: $10.14746 /$ bo.2021.1.9

Uniwersytet im. Adama Mickiewicza

\title{
Kolejna publikacja słownikowa o czeskich kulturemach
}

Omawiana praca ${ }^{1}$ składa się dwóch podstawowych części: teoretycznego wstępu z wykazem skrótów (Úvod, s. 3-12) i słownika (Abecedni slovník slov, rčení, príslovi a pořekadel, s. 13-186), uzupełnionych indeksem analizowanych form (Obsahovy rejstřik, s. 187-199), wykazem publikacji, z których zaczerpnięto materiał do słownika (Použitá literatura, s. 200-206), oraz dodatkiem, w którym znajduja się testy do samokontroli (Dodatky. Praktické úkoly a testy, s. 207-216). Całość zamyka bibliografia (Doporučená literatura, s. 217-220).

Publikacja Ludmily Danylenko mieści się w ramach lingwistyki kulturowej. Autorka bowiem przyjęła za cel opisanie tych form języka, których znaczenie kształtowało się w bezpośrednim związku ze zjawiskami szeroko rozumianej kultury (akt nominacji uwarunkowany zjawiskiem kultury). Jak pisze, ,považujeme slovo za kulturní znak. A jako kulturní znak má slovo kulturní pamět', která je dána at' už sémantikou, etymologií nebo narážkou na nějakou historickou událost, osobu, tradici, obyčej, a tak jsou slova rovněž i úsloví nevyčerpatelnými poklady kulturní minulosti a v ní jsou zakotveny" (s. 6). Zatem punktem wyjścia dla Autorki jest twierdzenie, że język narodowy to nie tylko „uchopení a pochopení světa i jeho interpretace” (s. 3), ale przede wszystkim , jako zhuštění ducha národa” to ważny element filozofii narodowej, obecny od momentu „wskrzeszenia” go „,v ideologii českého národního obrození” (s. 3). Przyjmując zatem takie założenie, należy zwrócić uwagę również na wiedzę pozajęzykową, która uzupełnia wiedze językowa jednego z podstawowych elementów języka (zasób słowny), a dokładniej poszerza kompetencję komuni-

${ }^{1}$ Ludmila Danylenko, Kulturní pamět slova. Přiručka české lingvokulturologie, Kyjev: Видавничний дім Дмитра Бураго, 2017, 221 s., ISBN 978-966-489-410-1. 
kacyjną, wykorzystywaną w tworzeniu aktów mowy w języku czeskim. W poszczególnych hasłach opracowanych przez Ludmiłę Danylenko ten element zawsze jest obecny, np.

\section{bohém}

- Bezstarostně, nesporádaně žijici nadaný člověk, zvl. umělec. bohémský život, kol., expr.

- Bezstarostný život.

- Ve 14. století se ve Francii objevili Romové. Když se je Francouzi ptali, odkud jsou, oni ř́kali, že z Bohemie. Francouzi začali pojmenovávat Romy slovem bohémiens. Od V. Machka se poučíme, že ze francouzštiny bohéme znamená cikánstvo (bohémien 'cikán', a to ze střlat. Bohemus obyvatel Bohemie $=$ Čech). Na „bohémy” bylo přeneseno vzhledem na jejich život sice často chudobný, ale volný, význam 'bezstarostný'. Začalo se tak říkat předevšín umělcům, lidem nadaným, ale vedoucím neukázněný život. Spořádaným Francouzi̊m připadalo, že se chovají prílišs hlučně, veselé, tedy podobně jako Romové.

- Opravdový bohém nemyslí na druhý den, celé noci zvedá číše a žije dobrodružný život, ale to na mně moc neplatí.

- Veselý bohém, věčný buřič a neúnavný filmař Jan Němec vydal vzpomínkovou knihu

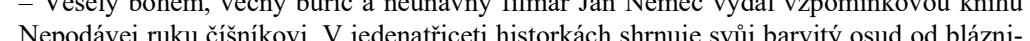
vých večírkủ až po návrat $\mathrm{z}$ Hollywoodu.

-Zdálo se, že má před sebou skvělou budoucnost. Ale zalíbil se mu bohémský život a brzy byl s dědictvím hotov. Aby se udržel, prodával za babku své práce, které ve chvatu odbýval.

Machek 1957: 37; HL 1968: 100-101; Rejzek 2001: 84; Novotný 2003: 13.

Kulturowy aspekt funkcjonowania słownictwa czeskiego jest bardzo ważny również w glottodydaktyce. Jest to drugi cel wspomnianego opracowania: włączenie się w proces glottodydaktyczny języka czeskiego jako obcego, aby pomóc osobom uczącym się tego języka w zrozumieniu tej warstwy zasobu leksykalnego czeszczyzny. To było głównym kryterium doboru haseł słownikowych, które miałyby być „především praktickým pomocníkem pro studenty” (s. 7), a także miałyby ukazywać „výraznou mozaikou českého národního lexikálního a frazeologického systému jako celek” (s. 7). Z tego względu jako materiał Autorka przyjęła wyrazy, frazeologizmy, przysłowia i porzekadła, w których elementem składowym jest określone zjawisko kultury i które są współcześnie używane. Tutaj widać pewną niejednorodność materiału. Autorka pisze, że są to:

- ,jednotky s vlastními jmény jednak skutečnými, jednak smyšlenými

- jednotky, které pocházejí z lidové slovesnosti, dějin, literatury ap.;

- jednotky přejaté z jiných jazyků (především antická a německá úsloví) a zcela vžité, zdomácnělé;

- jednotky, které obsahují názvy reálií, jevů tradičního života, zdvořilostní fráze;

- jednotky, které odrážejí lidové a náboženské zvyky a pověry, pranostiky;
- obrazná pojmenování lišící se od sebe obrazem, vnitřní formou v češtině a ukrajinštíně;

- slovní hříčky;

- přísloví a pořekadla všeobecně rozšířená a uživána v běžné komunikaci” (s. 7).

Zatem dobór haseł może wydawać się przypadkowy. Jednak jeśli weźmiemy pod uwagę doświadczenie dydaktyczne Autorki, to możemy sobie wyobrazić, dlaczego niektóre inne kulturemy nie znalazły się w omawianej pracy (np. sametová revoluce, Lidice, španělský ptáček, ale jest kanadský žert itd.; por. też artykuł Marii Čechovej 1993 czy Mieczysława Balowskiego 1998). Zatem są to te hasła, które najczęściej pojawiły się w trakcie pracy dydaktycznej Autorki i w zrozumieniu których studenci mieli problemy (czy też w odniesieniu do pierwotnego aktu nominacji).

Mimo powyżej opisanych ograniczeń omawianej publikacji Kulturni pamět' slova będzie bardzo pomocna dla studentów, a także dla sympatyków języka i kultury czeskiej.

\section{Literatura}

B a lo w s k i M., 1998, Kulturní kódy včeské publicistice, [w:] Pocta 650. výročízaloženi Univerzity Karlovy Praze, red. A. Stich, Praha: Karolinum, s. 11-20.

Če chová M. 1993, Kulturni frazeologie v současné komunikaci, Naše řě””, nr 4, s. 179-183. 